\title{
The effect of smoking on mortality in Hungary between 2000 and 2014*
}

\author{
András Wéber \\ Advisor \\ Hungarian Central Statistical \\ Office; \\ PhD student \\ University of Pécs \\ E-mail: Andras.Weber@ksh.hu
}

The aim of the research is to quantify the effect of smoking on mortality conditions between 2000 and 2014 in Hungary. To attain this objective, the methodology of CDC (Centers for Disease Control and Prevention, US) updated in 2013 is applied. First, smoking prevalence in the Hungarian population is examined using descriptive statistical tools, then the phenomenon and basic trends of smoking-attributable excess mortality are analysed by the variables of gender, age and causes of death. In addition, an outlook is given on the neighbouring countries, based on the WHOHFA (World Health Organization - Health for All) database.

According to the results, smoking is particularly dangerous for women: the smoking-attributable standardised death rate per 100000 women, caused by malignant neoplasms of the trachea, bronchus and lung has increased by $60 \%$. This may be due to mortality of older women aged 50 to 70 years, which is brought about by their increased nicotine dependence. Owing to the magnitude of excess mortality caused by addiction, smoking has had a significant impact on the mortality of the Hungarian population. From the turn of the millennium to the present day, nicotine addiction claimed more than 370000 lives in Hungary.

KEYWORDS:

Smoking.

Mortality.

DOI: 10.20311/stat2017.K21.en003

* The author expresses his thanks to Miklós Faragó for his assistance in performing the statistical calculations. 


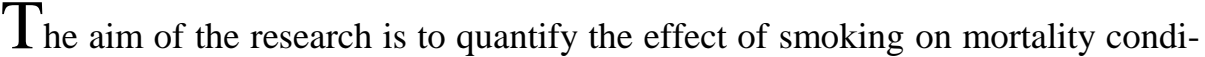
tions in one and a half decades after the turn of the millennium. However, this is not the first such an attempt in our country. The study of Péter Józan and László Radnóti that was published under the title "The impact of smoking on mortality in Hungary 1970-1999" (KSH [2002]) can be regarded as a pioneering work in the topic. Ten years later, József Vitrai and his co-authors published their analysis paper "The social burdens of smoking in Hungary" (Vitrai et al. [2012]). Afterwards, as a part of a periodical publication of the Hungarian Central Statistical Office, a study of András Wéber and Miklós Faragó on the impact of nicotine dependence on mortality was published (KSH [2014]). All the three studies applied the CDC-recommended procedure for the Hungarian conditions. The present study does not depart from this methodological recommendation either, but compared with the earlier ones, it uses its updated version (U.S. HHS CDC NCCDPHP Office on Smoking and Health [2014]) containing the results of the latest research.

In Hungary, the level of mortality is high compared not only with the Western European but also with the Visegrád countries, and within this, tobacco consumption is also a determining factor. Lifestyle factors have a decisive impact on the health of an individual, and smoking as a risk factor greatly damages the chances of life. This relationship was confirmed by Sir Richard Doll (an English epidemiologist who was the first to prove in the 1950s that nicotine addiction causes an increased risk of lung cancer and heart disease) and A. Bradford Hill (Doll-Hill [1950]). According to the recent research, the health-damaging effect of smoking is general and can be detected in the entire human body. Consequently, this addiction has a decisive role in the development of more than one, mostly chronic diseases leading to death.

Nor can we forget about the socio-economic costs of smoking. On the revenue side, there is a predictable and steady budgetary source in the form of excise tax and VAT. In contrast, on the expenditure side, there are the costs of curing tobaccorelated diseases (such as medicines, inpatient care), extra expenditures on health and social systems (sick pay, disability retirement, etc.) and the loss of deceased active women and men. After examining the balance of the total smoking-related individual and state expenditures and revenues, Vitrai et al. ([2012] p. 9.) estimated a nearly HUF 80 billion (!) loss in 2010.

Having regard to the above, all measures that are aimed at reducing the prevalence of smoking and promoting the prevention of this addiction are therefore justified, as additional deaths caused by nicotine addiction can be prevented (Vokó [2009]). Appropriate steps in this direction were the enactment of a ban on 1 January 2012 on smoking in closed public spaces and the increase of excise duties on tobacco products. 
Using descriptive statistical tools, the present study examines the phenomenon and basic trends of smoking-attributable excess mortality in Hungary by the variables of gender, age and causes of death from the turn of the millennium to the present day. In addition, an international outlook relying on the WHO-HFA database is also presented to introduce the situation in the neighbouring countries. The research primarily seeks to follow the goal of earlier works: "so that we can measure the results achieved in reducing this addiction" ( $K S H$ [2002] p. 9.).

\section{Prevalence of smoking ${ }^{1}$}

The precondition of calculating smoking-attributable excess mortality is to know prevalence of smoking. In the period observed by the research, the similarity of the data of four representative surveys (the National Health Interview Survey 2000, 2003 and the European Health Interview Survey 2009, 2014) allows the combined use of results (Vitrai et al. [2012]). Based on these surveys, the population of Hungary can be divided into three parts: current smokers, those who have quit smoking and who never smoked. Since prevalence is one of the bases for calculating smokingattributable mortality, its examination by gender and age is justified.

As indicated by the above health interview surveys, one in every two men and every third woman in Hungary is affected by nicotine dependence. According to the estimates of the questionnaire-based research, the absolute number of men who currently smoke or have quit smoking was more than 2.5 million at the turn of the millennium, but it fell to about 2.2 million by 2014. For women, the decline was lower: their corresponding figures were 1.75 million and around 1.65 million, respectively. This means that over one and a half decades, the base population of smokingattributable mortality decreased in the case of both sexes.

As a result, about 1.3 million men smoked according to the health interview survey in 2014, and the relevant figure for women remained steadily below 1 million. If we examine the estimates for smoking status with $95 \%$ confidence intervals by age group, a significant decrease can be seen among 40-44-year-old men in 2014 compared with 2000. Regarding the prevalence of smoking among women, a decline occurred in a wider age group, between 30 and 45 years of age. In contrast, the proportion of nicotine addicts among women aged 55-65 years has increased significantly since the turn of the millennium. Another unfavourable development is that there has been no decrease in the prevalence of smoking in the 18-30-year-old population since 2000.

\footnotetext{
${ }^{1}$ The proportion (frequency of occurrence) of individuals (in this case smokers) suffering from a certain disease in the total population.
} 
Figure 1. Prevalence of smoking by gender and age group, 2000 and 2014 (with $95 \%$ confidence intervals)

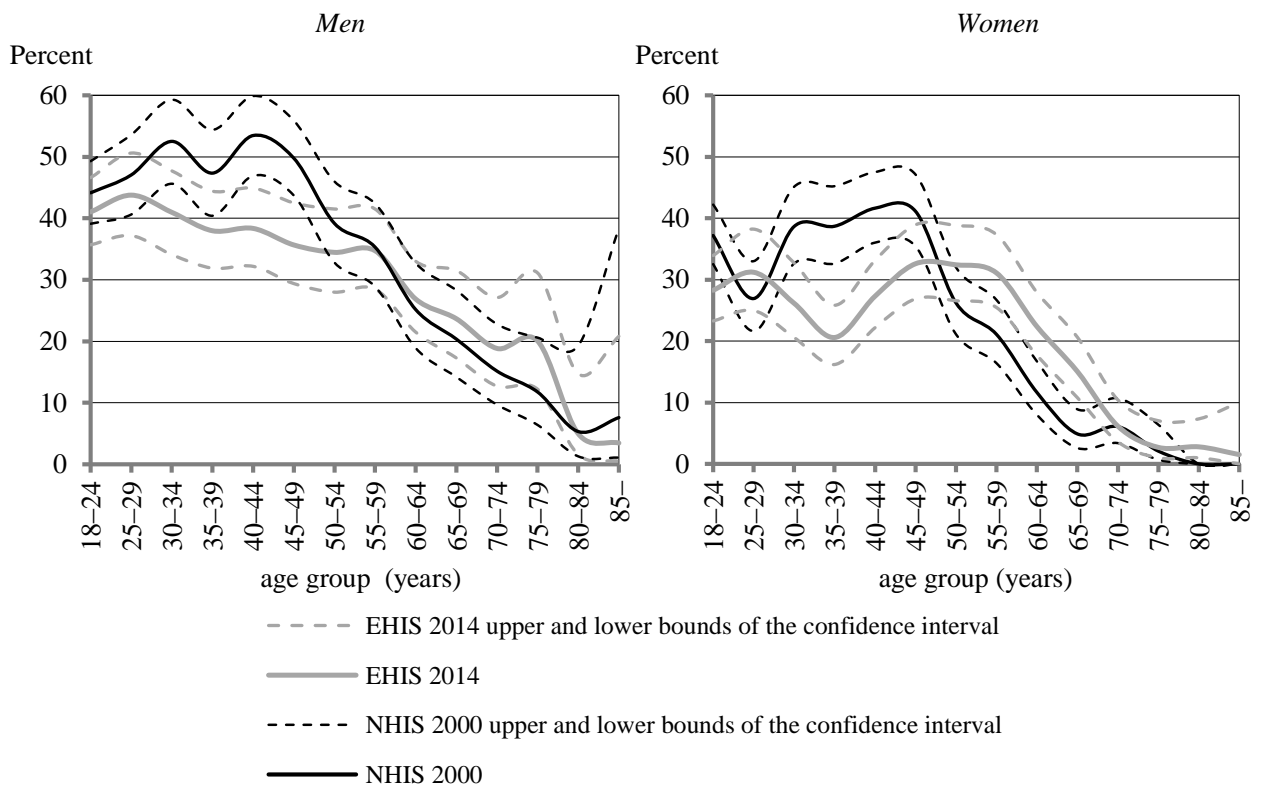

Source: Here and in the following figures and tables, own calculations.

Figure 2. Prevalence of non-smoking by gender and age group, 2000 and 2014

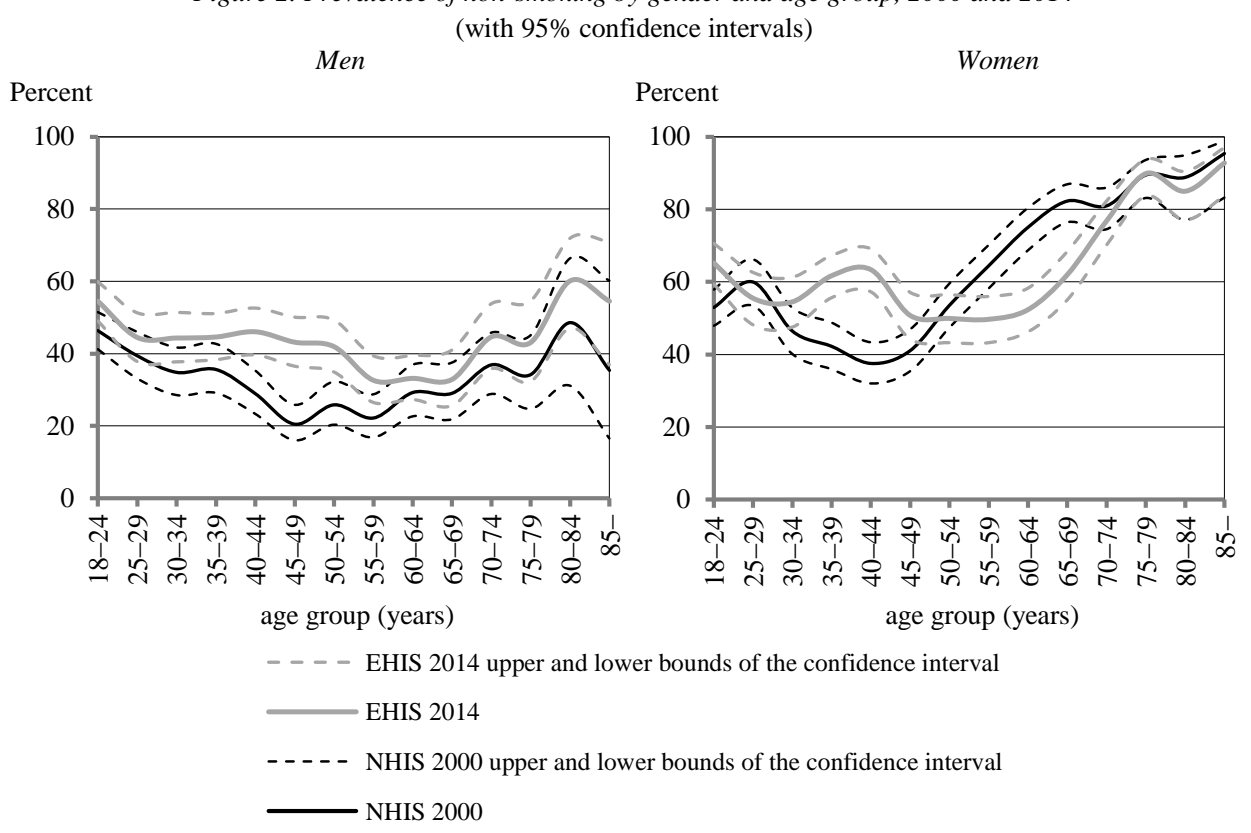

HUNGARIAN STATISTICAL REVIEW, SPECIAL NUMBER 21 
In line with the findings, non-smoking became significantly more common among 40-50-year-old men between 2000 and 2014. In parallel, the ratio of nonsmoking women aged 30-45 years in the female population also rose considerably, while the proportion of those who never smoked fell remarkably among older women aged 50-70 years.

In the case of those who have quit smoking, significant changes could only be observed in the female population during the observed period. In the prevalence of smoking among such women, there has been a slight reduction around the age of 40 and an increase in the 60-65 age group.

Figure 3. Prevalence of ex-smoking by gender and age group, 2000 and 2014 (with $95 \%$ confidence intervals)

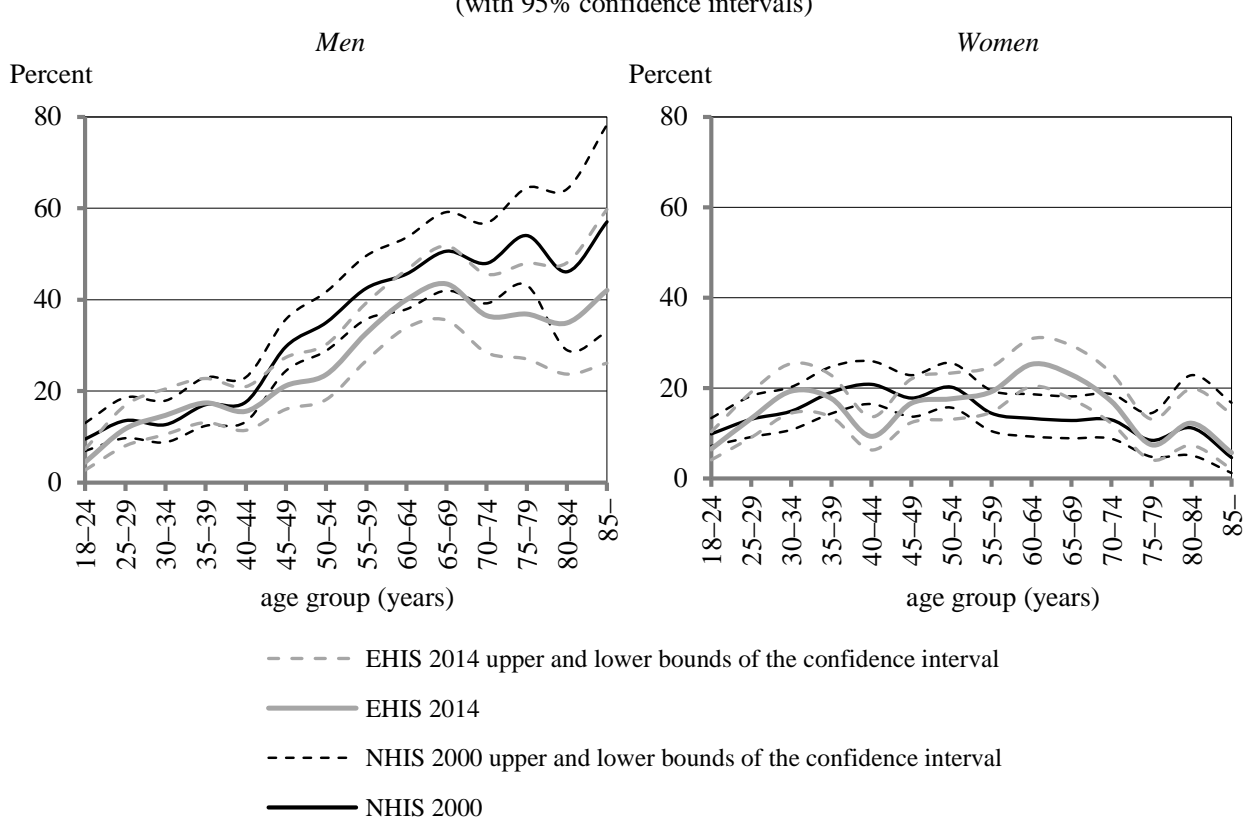

\section{Smoking-attributable mortality}

"By the definition, "ssmoking-attributable mortality due to a certain cause of death « in a population means that how many persons would not have died out of those suffering from the given cause of death if their death rate had equalled the one of non-smokers." (KSH [2014] p. 30.) Based on CDC instructions, the research relies 
on three data sources: 1. relative risks, 2. smoking prevalence and 3. the number of deaths due to certain causes of death.

Relative risks quantify the health risks of tobacco use among smokers and exsmokers compared with non-smokers. These measures are known by group of diseases as well. For example, according to the methodology updated in 2013, the chances of a 65-74-year-old smoking man to die of lung cancer is more than 28-fold compared with a non-smoking man. Accordingly, the relative risk for non-smokers is always 1. In general, these multipliers are lower for women, ex-smokers and for younger age groups. Due to the slow progression of smoking-associated diseases and the fact that addiction usually begins when people are in their teens, the methodology assumes that no one dies from diseases caused by nicotine addiction before the age of 35. (Smoking may cause infrequently fatal accidents as well, but their number is insignificant.) The few - fortunately very rare - exceptions are those cases when an infant death occurs due to the mother's smoking during pregnancy.

Smoking prevalence rates for the Hungarian population are known from the health interview surveys (NHIS 2000, NHIS 2003, EHIS 2009, EHIS 2014) for the period between 2000 and 2014. For intermediate years, a statistical approximation method was applied. The number of deaths due to certain smoking-associated causes of death by age group is available from the causes of death database of the Hungarian Central Statistical Office. The calculations resulted in the numbers of smoking-attributable excess deaths by cause of death, gender and 5-year age group between 2000 and 2014.

Generally, approximately one in every five deceased persons dies because of smoking every year in Hungary. During the observed one and a half decades, the absolute number of deaths associated with nicotine dependence stagnated around 25 thousand. As a result of the decline in overall mortality and the stagnation of the absolute number of persons died as a result of addiction, the proportion of smokingattributable mortality within the total number of deaths slightly increased in the examined period. However, the standardised death rate that eliminates the impact of the different age structure of the Hungarian population compared with that of the European population decreased by nearly $14 \%$ between 2000 and 2014 .

Table 1

\begin{tabular}{c|c|c|c}
\multicolumn{4}{c}{$\begin{array}{c}\text { Number of smoking-attributable excess deaths, their proportion within total mortality } \\
\text { and smoking-attributable standardised death rate per 100 000 persons, 2000-2014 }\end{array}$} \\
\hline \multirow{2}{*}{ Year } & $\begin{array}{c}\text { Number of smoking- } \\
\text { attributable deaths }\end{array}$ & $\begin{array}{c}\text { Smoking-attributable standardised } \\
\text { death rate per } 100000 \text { persons* }\end{array}$ & $\begin{array}{c}\text { Percentage of smoking-attributable } \\
\text { deaths within total mortality }\end{array}$ \\
\hline \multirow{2}{*}{2000} & 24816 & 297.48 & 18.30 \\
\cline { 2 - 4 } & $(20353-31168)$ & $(236.22-391.86)$ & $(15.01-22.99)$ \\
\hline \multicolumn{3}{c}{} & \multicolumn{2}{c}{ (Continued on the next page) }
\end{tabular}




\begin{tabular}{|c|c|c|c|}
\hline Year & $\begin{array}{l}\text { Number of smoking- } \\
\text { attributable deaths }\end{array}$ & $\begin{array}{l}\text { Smoking-attributable standardised } \\
\text { death rate per } 100000 \text { persons* }\end{array}$ & $\begin{array}{l}\text { Percentage of smoking-attributable } \\
\text { deaths within total mortality }\end{array}$ \\
\hline \multirow[t]{2}{*}{2001} & 24093 & 286.01 & 18.23 \\
\hline & (19 675-30 424) & $(226.25-379.77)$ & $(14.88-23.02)$ \\
\hline \multirow[t]{2}{*}{2002} & 24258 & 286.59 & 18.26 \\
\hline & (19 704-30 855) & (225.09-385.45) & (14.83-23.23) \\
\hline \multirow[t]{2}{*}{2003} & 25040 & 293.50 & 18.44 \\
\hline & (20 307-31 969) & $(229.88-397.96)$ & $(14.95-23.54)$ \\
\hline \multirow[t]{2}{*}{2004} & 24723 & 287.30 & 18.66 \\
\hline & $(20027-31510)$ & $(224.63-388.56)$ & $(15.12-23.78)$ \\
\hline \multirow[t]{2}{*}{2005} & 25551 & 295.23 & 18.82 \\
\hline & $(20611-32$ 695) & $(230.06-399.37)$ & $(15.19-24.09)$ \\
\hline \multirow[t]{2}{*}{2006} & 24744 & 282.42 & 18.80 \\
\hline & $(20033-31451)$ & $(221.80-376.33)$ & $(15.22-23.90)$ \\
\hline \multirow[t]{2}{*}{2007} & 25263 & 285.95 & 19.00 \\
\hline & $(20448-32067)$ & $(225.07-378.37)$ & $(15.38-24.12)$ \\
\hline \multirow[t]{2}{*}{2008} & 24759 & 278.07 & 19.04 \\
\hline & (19 984-31 452) & $(218.60-366.61)$ & $(15.37-24.19)$ \\
\hline \multirow[t]{2}{*}{2009} & 25143 & 280.09 & 19.28 \\
\hline & $(20$ 233-31 943) & $(219.81-368.03)$ & $(15.51-24.49)$ \\
\hline \multirow[t]{2}{*}{2010} & 25035 & 275.99 & 19.19 \\
\hline & $(20206-31901)$ & $(217.79-363.01)$ & $(15.49-24.45)$ \\
\hline \multirow[t]{2}{*}{2011} & 24782 & 270.23 & 19.24 \\
\hline & $(20082-31556)$ & $(214.71-354.09)$ & $(15.59-24.50)$ \\
\hline \multirow[t]{2}{*}{2012} & 24913 & 269.08 & 19.25 \\
\hline & $(20$ 255-31 735) & $(213.82-354.79)$ & $(15.65-24.52)$ \\
\hline \multirow[t]{2}{*}{2013} & 24338 & 260.40 & 19.20 \\
\hline & $(19829-31074)$ & $(207.69-343.73)$ & $(15.64-24.51)$ \\
\hline \multirow[t]{2}{*}{2014} & 24263 & 256.18 & 19.21 \\
\hline & (19 889-30 907) & $(206.10-336.63)$ & $(15.75-24.47)$ \\
\hline
\end{tabular}

* The values were generated for 100000 persons and standardised for the age structure of the European population as recommended by Eurostat.

Note. The brackets contain $95 \%$ confidence intervals. 
Figure 4. Smoking-attributable and non-smoking-attributable standardised death rate, 2000-2014 (with $95 \%$ confidence intervals)

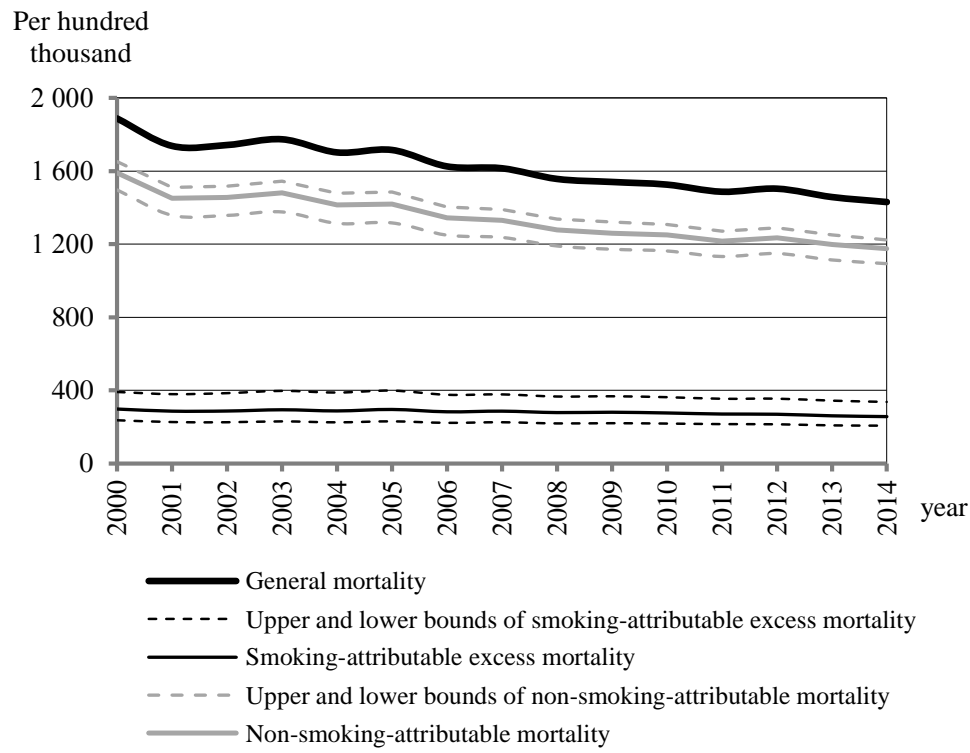

\section{Differences in smoking-attributable excess mortality by gender}

In the observed period, the absolute number of smoking-attributable excess mortality of men decreased by $13 \%$ and amounted to 16754 persons in 2014; the measure for women increased by more than one third, exceeding 7500 at present. Consequently, the percentage of men who died because of nicotine dependence within total mortality stagnated during one and a half decades, while that of women increased considerably, by 3.2 percentage points. About one in every four deaths of men (27\%) and one in every ten deaths of women (12\%) could be attributed to smoking in 2014.

At the turn of the millennium, three and a half times more men died due to smoking than women. The nicotine-dependence-related excess mortality rate of men compared with that of women increased until 2003, then, because of a spectacular decline, the difference fell by one third by the end of the observed period, decreasing significantly the gender gap. While the relevance of smoking to men's general mortality has fallen, the addiction of women, which was less important in the past, became more substantial in the last one and a half decades. 
Table 2

Number of smoking-attributable excess deaths and their proportion within total mortality by gender,

2000-2014

\begin{tabular}{|c|c|c|c|c|}
\hline \multirow{3}{*}{ Year } & \multirow{2}{*}{\multicolumn{2}{|c|}{ Number of persons deceased due to smoking }} & \multicolumn{2}{|c|}{ Percentage of } \\
\hline & & & men & women \\
\hline & Men & Women & deceased due to $\mathrm{s}$ & hin total mortality \\
\hline \multirow[t]{2}{*}{2000} & 19300 & 5517 & 27.39 & 8.47 \\
\hline & $(16421-23030)$ & (3 932-8 138) & $(23.30-32.68)$ & $(6.04-12.50)$ \\
\hline \multirow[t]{2}{*}{2001} & 18754 & 5339 & 27.42 & 8.37 \\
\hline & $(15850-22438)$ & $(3825-7986)$ & $(23.18-32.81)$ & $(6.00-12.52)$ \\
\hline \multirow[t]{2}{*}{2002} & 18903 & 5356 & 27.46 & 8.37 \\
\hline & (15 851-22 708) & (3 852-8 148) & $(23.03-32.99)$ & $(6.02-12.73)$ \\
\hline \multirow[t]{2}{*}{2003} & 19617 & 5424 & 28.02 & 8.24 \\
\hline & $(16376-23545)$ & (3 931-8 424) & $(23.39-33.63)$ & $(5.97-12.80)$ \\
\hline \multirow[t]{2}{*}{2004} & 18984 & 5738 & 27.76 & 8.95 \\
\hline & (15 877-22 722) & (4 151-8 789) & $(23.22-33.23)$ & $(6.47-13.71)$ \\
\hline \multirow[t]{2}{*}{2005} & 19296 & 6254 & 27.65 & 9.48 \\
\hline & $\left(\begin{array}{l}16 \\
111\end{array}-23139\right)$ & (4 501-9 556) & $(23.09-33.16)$ & $(6.82-14.49)$ \\
\hline \multirow[t]{2}{*}{2006} & 18492 & 6252 & 27.25 & 9.81 \\
\hline & $\left(\begin{array}{l}15 \\
502-22\end{array} 079\right)$ & $(4$ 531-9 372) & $(22.85-32.54)$ & $(7.11-14.70)$ \\
\hline \multirow[t]{2}{*}{2007} & 18488 & 6774 & 27.09 & 10.47 \\
\hline & (15 505-22 044) & $\left(\begin{array}{l}4 \\
4\end{array} 942-10023\right)$ & $(22.72-32.30)$ & $(7.64-15.49)$ \\
\hline \multirow[t]{2}{*}{2008} & 17843 & 6915 & 26.93 & 10.85 \\
\hline & (14 952-21 247) & 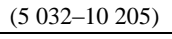 & $(22.56-32.06)$ & $(7.89-16.01)$ \\
\hline \multirow[t]{2}{*}{2009} & 17853 & 7290 & 26.92 & 11.37 \\
\hline & $(14941-21221)$ & (5 292-10 723) & $(22.53-32.00)$ & $(8.26-16.73)$ \\
\hline \multirow[t]{2}{*}{2010} & 17640 & 7395 & 27.08 & 11.32 \\
\hline & $(14827-20929)$ & (5 378-10 972) & $(22.76-32.13)$ & $(8.23-16.80)$ \\
\hline \multirow[t]{2}{*}{2011} & 17373 & 7409 & 27.20 & 11.41 \\
\hline & $(14660-20580)$ & (5 422-10 977) & $(22.95-32.21)$ & $(8.35-16.91)$ \\
\hline \multirow[t]{2}{*}{2012} & 17353 & 7560 & 27.33 & 11.47 \\
\hline & $(14706-20519)$ & $(5$ 549-11 215) & $(23.16-32.31)$ & $(8.42-17.01)$ \\
\hline \multirow[t]{2}{*}{2013} & 16820 & 7518 & 27.18 & 11.59 \\
\hline & (14 289-19 899) & $\left(\begin{array}{l}5 \\
539-11\end{array}\right.$ & $(23.09-32.15)$ & $(8.54-17.22)$ \\
\hline \multirow[t]{2}{*}{2014} & 16754 & 7509 & 27.03 & 11.68 \\
\hline & (14 308-19 771) & $\left(\begin{array}{l}5 \\
582-11\end{array}\right.$ & (23.08-31.89) & $(8.68-17.31)$ \\
\hline
\end{tabular}

Note. The brackets contain $95 \%$ confidence intervals. 
Figure 5. Estimated proportion of smoking-attributable excess mortality within total mortality by gender, 2014

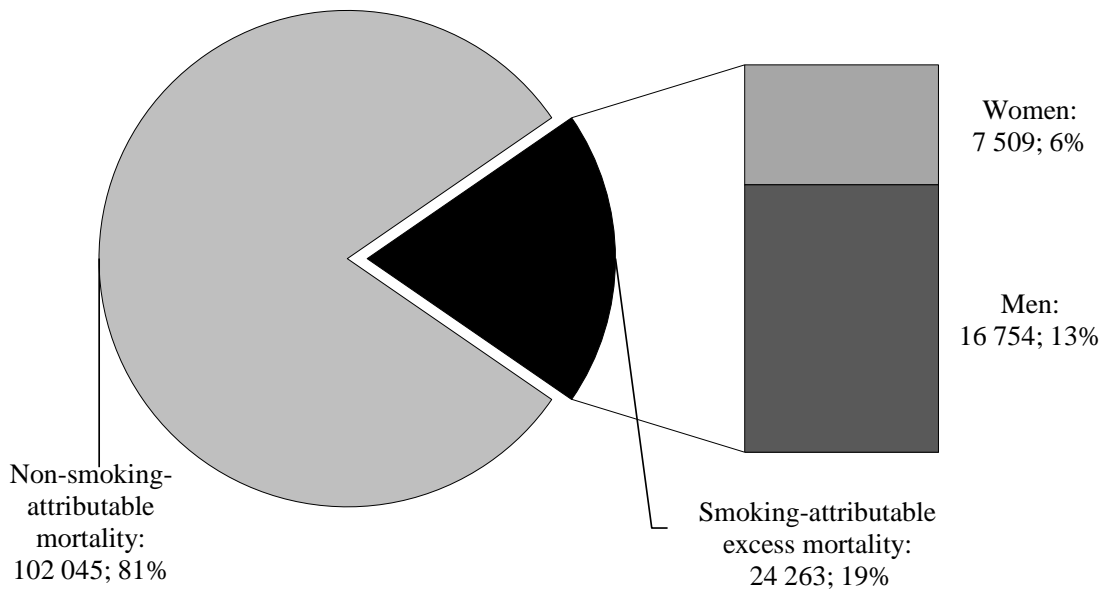

Figure 6. Smoking-attributable and non-smoking-attributable standardised death rate by gender, 2000-2014 (with $95 \%$ confidence intervals)

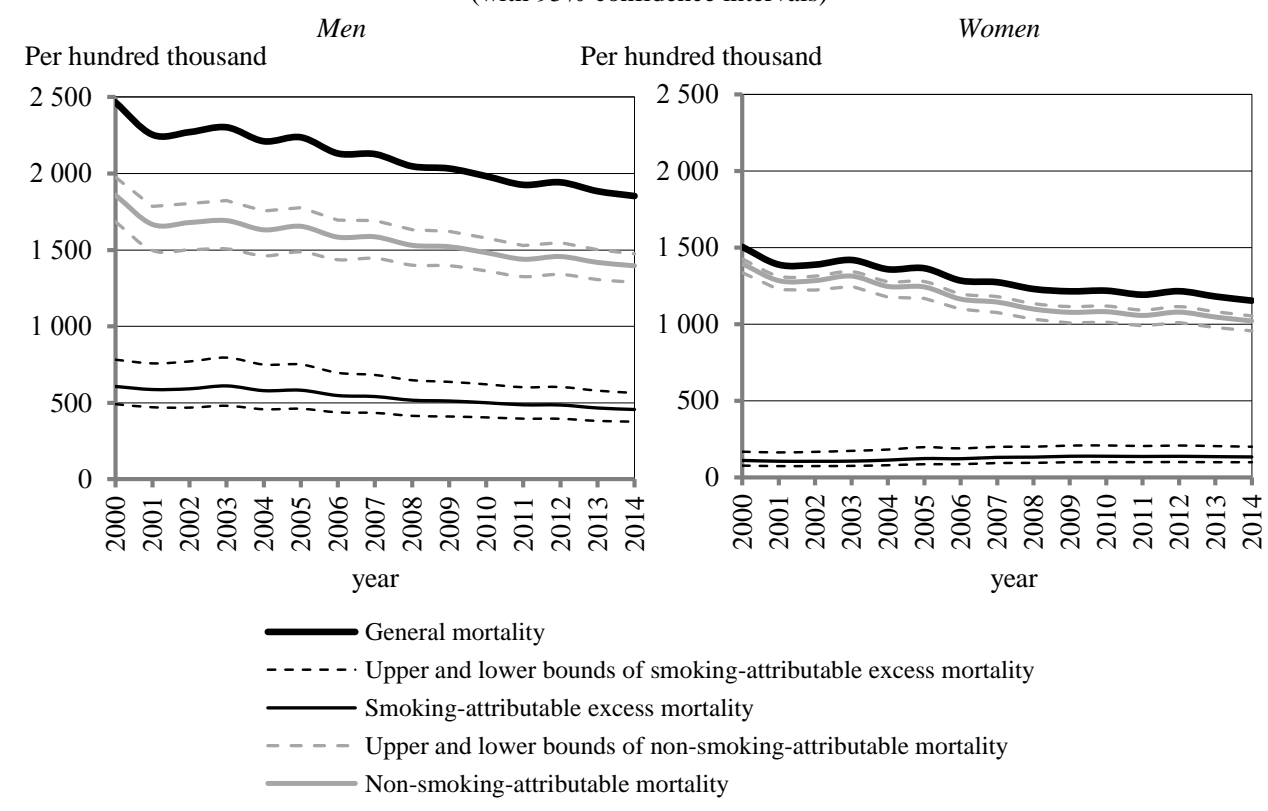

HuNGARIAN Statistical REVIEW, SPECIAL NUMBER 21 
Figure 7. Smoking-attributable excess male mortality per 100 women, 2000-2014 (with $95 \%$ confidence intervals)

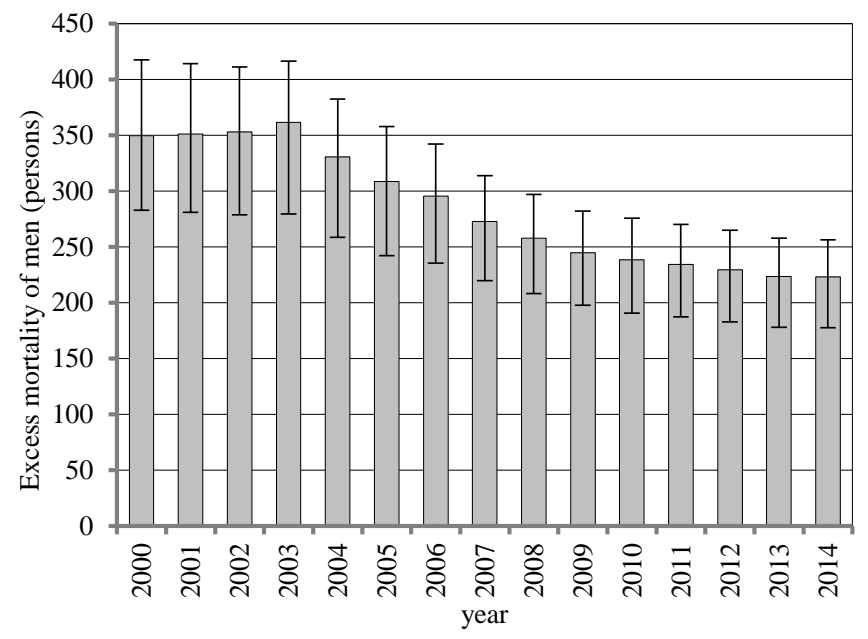

\section{Age structure of smoking-attributable excess mortality}

Examining the relative weight of each ten-year age group over 35 years, we can conclude that nicotine dependence requires more and more victims along with increasing age. Between 2000 and 2014, smoking-attributable standardised death rate of both sexes declined significantly in the 35-44 and 45-54 age groups: by $63 \%$ in the younger and by $44 \%$ in the older age group of men and by $67 \%$ and $15 \%$ respectively for women. By contrast, the rate grew significantly (by 56\%) in the case of older, 55-64-year-old women. After one and a half decades, the gender differences, apart from the 35-44 age group, became considerably smaller in all ages, especially in the age over 85 years. (See Figure 9.) In 2014, these differences increased by the progress of age and grew from about three-fold in the age group of 35-64 to nearly four-fold over 65 years of age. In the reference period, the decline in smokingattributable excess mortality was the largest in the 35-54 age group of both sexes. (See Figure 9.) In ages over 54, this figure was above 1 for men and below 1 for women, which means that the extent of smoking-attributable mortality of men decreased and that of women increased between 2000 and 2014. 
Figure 8. Smoking-attributable standardised death rate by gender and age group, 2000 and 2014 (with $95 \%$ confidence intervals)

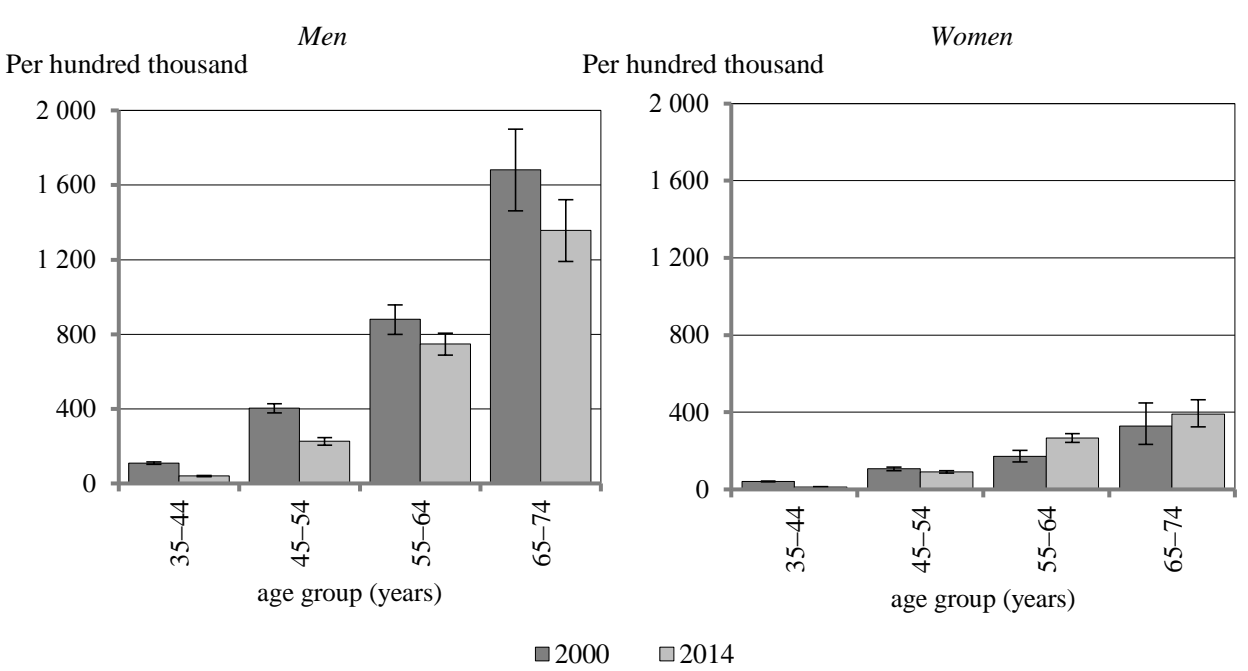

Figure 9. Smoking-attributable excess mortality by age group (estimates)

How many times it was greater for men than for women, 2000 and 2014

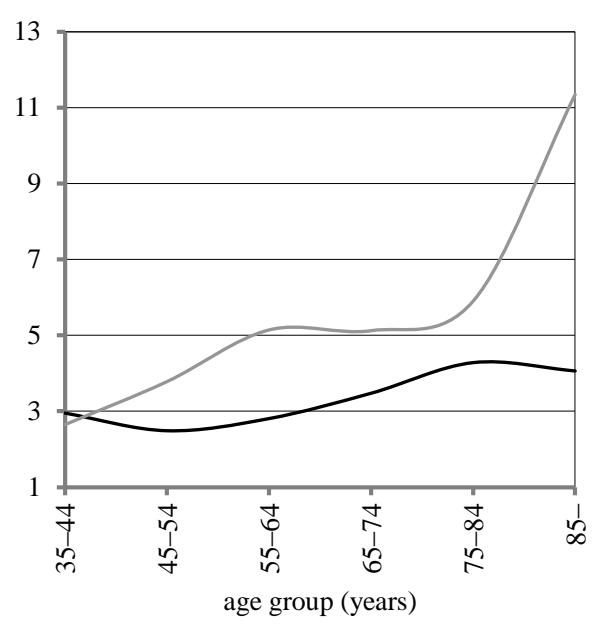

How many times it was greater in 2000 than in 2014 by gender

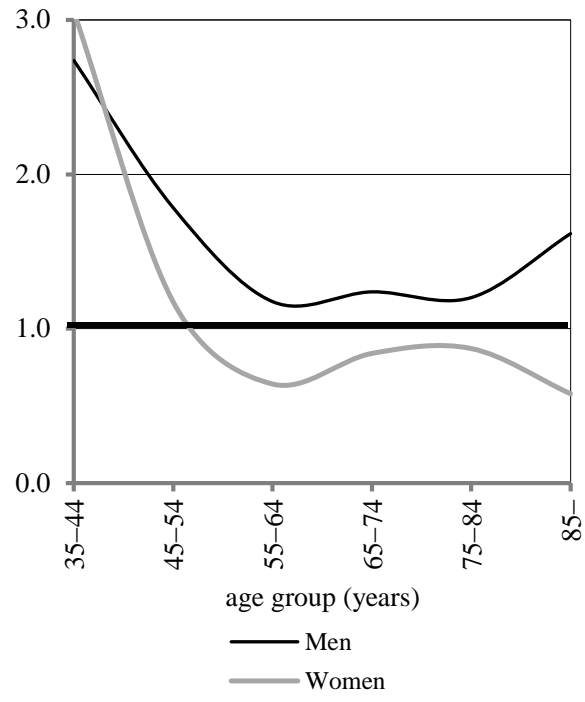


Table 3

Smoking-attributable standardised death rate per 100000 persons by gender and age group, 2000 and 2014

\begin{tabular}{|c|c|c|c|c|c|c|c|}
\hline \multirow{2}{*}{ Year } & $35-44$ & $45-54$ & $55-64$ & $65-74$ & $75-84$ & $85-$ & Total \\
\hline & \multicolumn{7}{|c|}{ year-old } \\
\hline \multirow{3}{*}{2000} & \multicolumn{7}{|c|}{ men } \\
\hline & 110.1 & 404.2 & 880.9 & 1681.6 & 2096.4 & 4464.8 & 606.6 \\
\hline & $(103.2-116.1)$ & $(377.9-427.9)$ & (798.7-957.6) & $(1462.0-1898.8)$ & $(1588.4-2757.1)$ & $(2627.2-8264.9)$ & $(489.6-781.1)$ \\
\hline \multirow[t]{2}{*}{2014} & 40.2 & 226.6 & 749.3 & 1357.5 & 1745.0 & 2763.2 & 456.1 \\
\hline & $(36.7-43.5)$ & (205.4-246.3) & $(688.5-805.9)$ & $(1190.0-1521.1)$ & $(1350.1-2230.2)$ & $(1785.9-4700.1)$ & $(377.3-563.5)$ \\
\hline \multirow{3}{*}{2000} & \multicolumn{7}{|c|}{ women } \\
\hline & 41.6 & 106.9 & 171.3 & 328.2 & 355.4 & 393.5 & 109.6 \\
\hline & $(38.8-44.2)$ & $(98.1-115.2)$ & $(143.0-201.9)$ & $(233.6-449.2)$ & $(184.5-650.0)$ & $(109.3-1207.7)$ & $(76.3-167.1)$ \\
\hline \multirow[t]{2}{*}{2014} & 13.6 & 91.1 & 267.0 & 390.8 & 407.7 & 680.2 & 132.6 \\
\hline & $(12.1-15.1)$ & $(84.0-97.8)$ & $(244.2-289.0)$ & $(324.6-465.1)$ & (231.4-681.6) & $(203.2-2138.2)$ & (98.2-198.5) \\
\hline
\end{tabular}

Note. The brackets contain $95 \%$ confidence intervals.

\section{Causes of death structure of smoking-attributable excess mortality $^{2}$}

In respect of public health, not only the age of a deceased smoker is an important issue but also the cause why the death has occurred. The latter can be analysed by the structure of the causes of death, the change of which is basically influenced by two factors: 1 . What progress has been made in medical science over the period in terms of curing and preventing a disease leading to death; 2 . How the number of persons in the various age groups exposed to the possible cause of death (in other words, the age structure of the population) has changed.

In 2014, the most smoking-attributable deaths of men, a total of 4702 , were caused by malignant neoplasms of the trachea, bronchus and lung. Ischaemic heart diseases are the second in the ranking with a similar value, followed by other malignant neoplasms as well as bronchitis, emphysema and COPD (chronic obstructive pulmonary disease) at a lower level. A more than $30 \%$ increase can be observed in

\footnotetext{
${ }^{2}$ The method of processing causes of death data was changed in 2005. Manual coding has been replaced by automated processing in which the coding of diagnose texts and the selection among underlying causes are carried out by a software. Therefore, there are breaks in the time series of causes-of-deaths data between 2004 and 2005 .
} 
mortality from the last four illnesses between 2000 and 2014, and by now their absolute number have reached the number of 2342 of other malignant neoplasms.

Among women, trachea, bronchus and lung cancers were also the most dangerous, altogether 2378 women died from these diseases due to their nicotine dependence. They were followed by ischaemic heart diseases, bronchitis, emphysema, COPD and other malignant neoplasms. In 2014, 44\% more women died of malignant neoplasms of the trachea, bronchus and lung and twice as many (numerically 1352 ) smoking women deceased due to bronchitis, emphysema and COPD than at the turn of the millennium.

Figure 10. Absolute numbers of smoking-attributable excess mortality by gender and cause of death, 2000 and 2014

Men

Number of cases

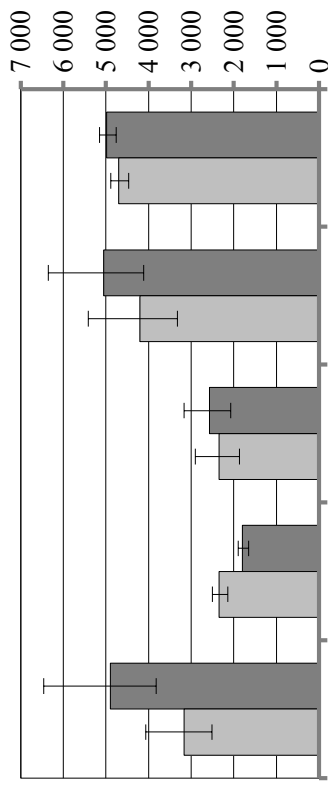

(with $95 \%$ confidence intervals)

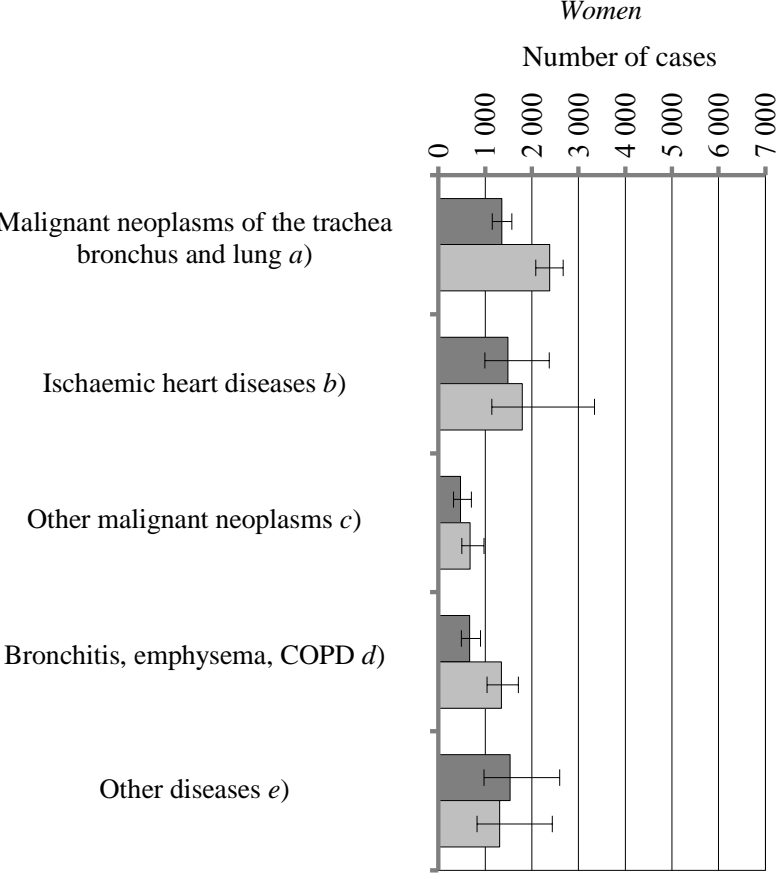

$\square 2000 \square 2014$

Note. According to the International Classification of Diseases, $10^{\text {th }}$ Revision: a) C33-C34; b) I20-I25; c) $\mathrm{C} 00-\mathrm{C} 14, \mathrm{C} 15, \mathrm{C} 16, \mathrm{C} 25, \mathrm{C} 32$, C53, C64-C65, C67, C22, C18-20, C92; d) J40-J42, J43, J44; e) I05-I09, I26I28, I11, I13, I30-I51, I60-I69, I70, I71, I72-I78, E10-E14, J09-J18, A15-A19, P07, P22, P23-P28, R95.

Based on the smoking-attributable standardised death rates per 100000 persons in 2014, we can conclude that more than half of the smoking-related deaths of men was caused by malignant neoplasms of the trachea, bronchus and lung having the 
same weight and by ischemic heart diseases. Compared with the turn of the millennium, the relative relevance of each disease category associated with this harmful addiction has increased among men at the expense of other diseases. In the case of women, trachea, bronchus and lung cancers are responsible for one in every three smoking-attributable deaths. Note that the relative relevance of this dangerous disease group has increased by 7.7 percentage points since 2000. In contrast, ischemic heart diseases are responsible for one in every four tobacco-related deaths of women, and their relative importance has decreased by 3 percentage points since the turn of the millennium. Smoking-related mortality due to bronchitis, emphysema and COPD should be also mentioned as the relative relevance of these diseases showed a spectacular increase for both sexes in the last one and a half decades.

Table 4

Distribution of the estimated value of the standardised death rate per 100000 persons by gender and cause of death, 2000 and 2014 (percentage)

\begin{tabular}{|c|c|c|c|c|c|c|}
\hline Year & $\begin{array}{l}\text { Malignant } \\
\text { neoplasms of the } \\
\text { trachea, bron- } \\
\text { chus and lung }\end{array}$ & $\begin{array}{c}\text { Ischaemic heart } \\
\text { diseases }\end{array}$ & $\begin{array}{c}\text { Other malignant } \\
\text { neoplasms }\end{array}$ & $\begin{array}{l}\text { Bronchitis, } \\
\text { emphysema, } \\
\text { COPD }\end{array}$ & Other diseases & Total \\
\hline & \multicolumn{6}{|c|}{ Men } \\
\hline 2000 & 23.3 & 25.7 & 12.7 & 8.3 & 30.0 & 100.0 \\
\hline \multirow[t]{2}{*}{2014} & 26.1 & 26.0 & 13.5 & 11.5 & 22.9 & 100.0 \\
\hline & \multicolumn{6}{|c|}{ Women } \\
\hline 2000 & 23.9 & 27.0 & 8.3 & 11.1 & 29.7 & 100.0 \\
\hline 2014 & 31.6 & 24.0 & 8.8 & 15.9 & 19.7 & 100.0 \\
\hline
\end{tabular}

In 2014, trachea, bronchus and lung cancers as well as ischaemic heart diseases were responsible for $52 \%$ of smoking-attributable excess mortality among men and for $56 \%$ among women. This justifies the detailed analysis of these two disease categories by gender, time series and age group. Another aim of this part of the research is to present the very different epidemiological nature of trachea, bronchus and lung cancers and ischaemic heart diseases.

Between 2000 and 2014, the smoking-attributable standardised death rate due to malignant neoplasms of the trachea, bronchus and lung per 100000 persons fell by $16 \%$ (with interruptions) for men and grew considerably, by $60 \%$ for women (the increase was continuous). The decrease in the age-specific rate of the 35-75 age group of men per 100000 persons has contributed primarily to the decline, and the mortality of 50-70-year-old women caused by their alarmingly increasing nicotine 
addiction has been in the background of the high rise observed. About nine in every ten deaths of men due to lung cancer are related to smoking; the corresponding figure of women is less than 6-8. Between 2000 and 2014, this measure improved considerably among 35-50-year-old men and 35-45-year-old women. However, the opposite is true for 55-65-year-old, middle-aged women: the proportion of their smokingattributable excess mortality showed a significant increase in deaths caused by malignant neoplasms of the trachea, bronchus and lung.

Figure 11. Smoking-attributable standardised death rate due to malignant neoplasms of the trachea, bronchus and lung per 100000 persons by gender, 2000-2014 (with $95 \%$ confidence intervals)

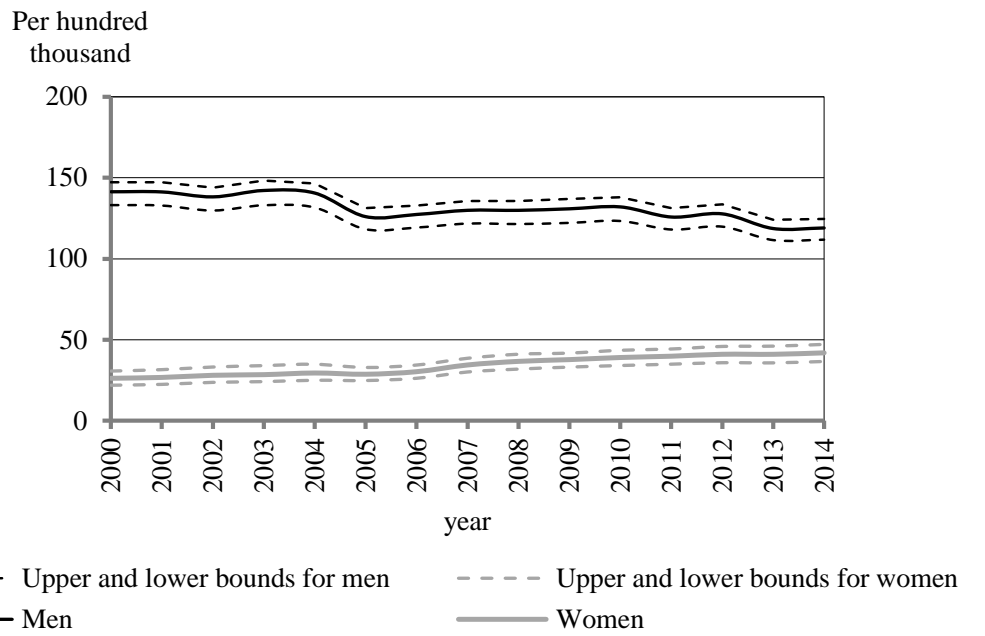

In the reference period, smoking-attributable death rate due to ischaemic heart diseases per 100000 persons, fell by $24 \%$ among men and rose by $7 \%$ among women. For the latter, the indicator peaked around 2010, and since then a slight decrease has been observed. In the case of men, the significant decline was owing to the moderate smoking of the 35-65-year-olds, while the age-specific indicator of women rose considerably only among the 60-65-year-olds. Examining the proportion of smoking-attributable excess mortality in deaths caused by ischaemic heart diseases, we can conclude that generally fewer deaths can be associated with smoking than in the case of trachea, bronchus and lung cancers. As for smoking-related lung cancer, the value of the indicator improved significantly among men aged 35-50 years and women aged 35-45 years between 2000 and 2014. However, the 55-65 female age group is more affected nowadays by smoking-attributable mortality due to ischaemic heart diseases than at the turn of the millennium. 
Figure 12. Age-specific smoking-attributable excess mortality caused by malignant neoplasms of the trachea, bronchus and lung per 100000 persons by gender and age group, 2000 and 2014

(with $95 \%$ confidence intervals)

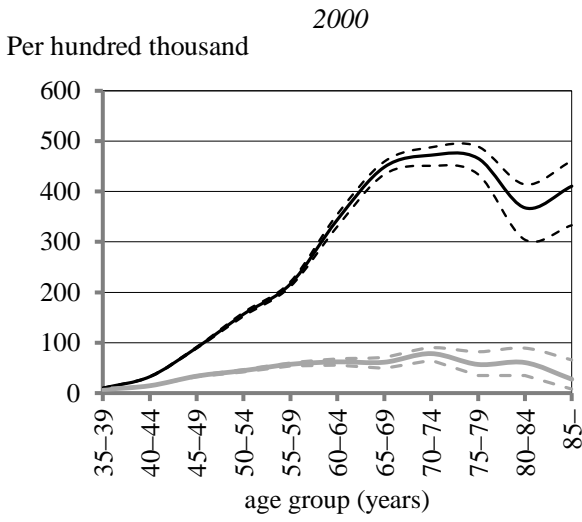

- - - - Upper and lower bounds for men

Men
Per hundred thousand

2014

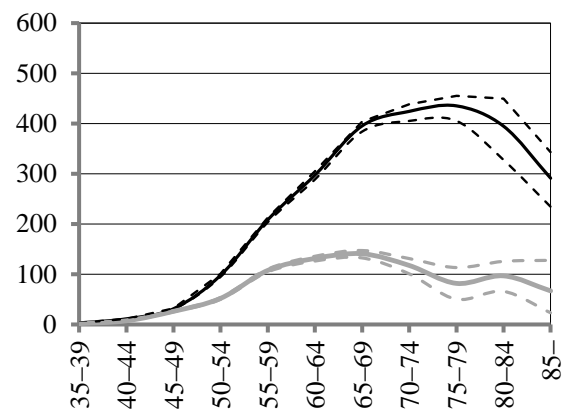

age group (years)

- - - Upper and lower bounds for women

Women

Figure 13. Proportion of smoking-attributable excess mortality in deaths caused by malignant neoplasms of the trachea, bronchus and lung in the population aged 35 years and over by gender and age group, 2000 and 2014 (with $95 \%$ confidence intervals)

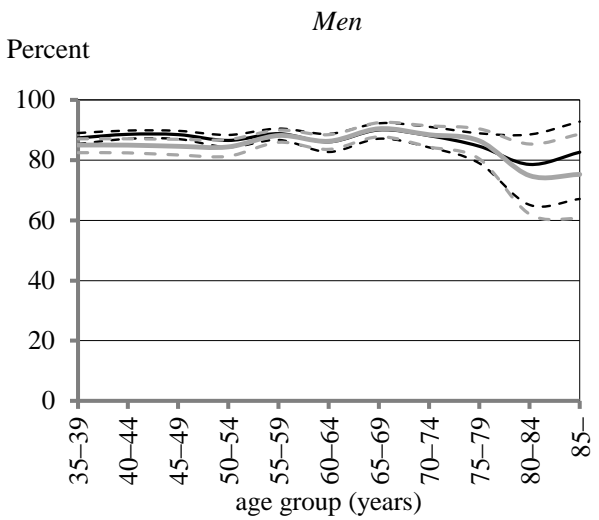

- - - - Upper and lower bounds in 2000 2000
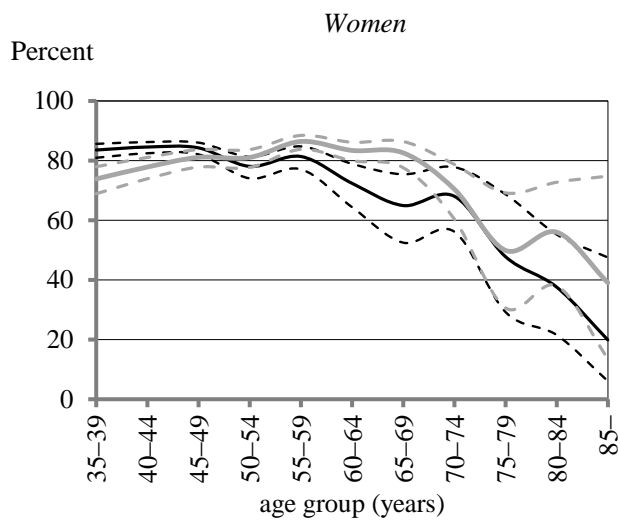

Upper and lower bounds in 2014 2014 
Figure 14. Smoking-attributable standardised death rate due to ischaemic heart diseases per 100000 persons by gender, 2000-2014

(with $95 \%$ confidence intervals)

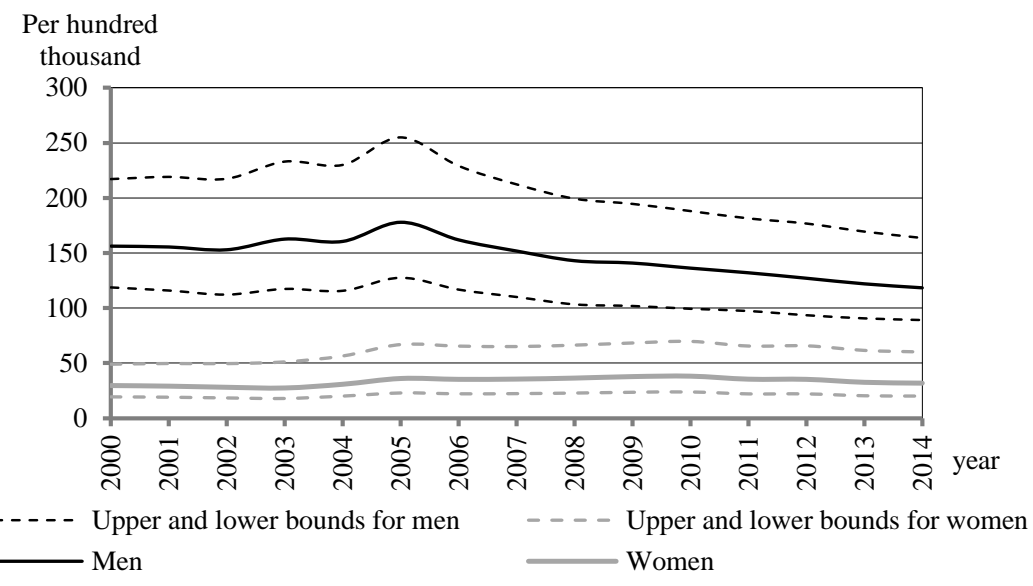

Figure 15. Age-specific smoking-attributable excess mortality caused by ischaemic heart diseases per 100000 persons by gender and age group, 2000 and 2014 (with $95 \%$ confidence intervals)

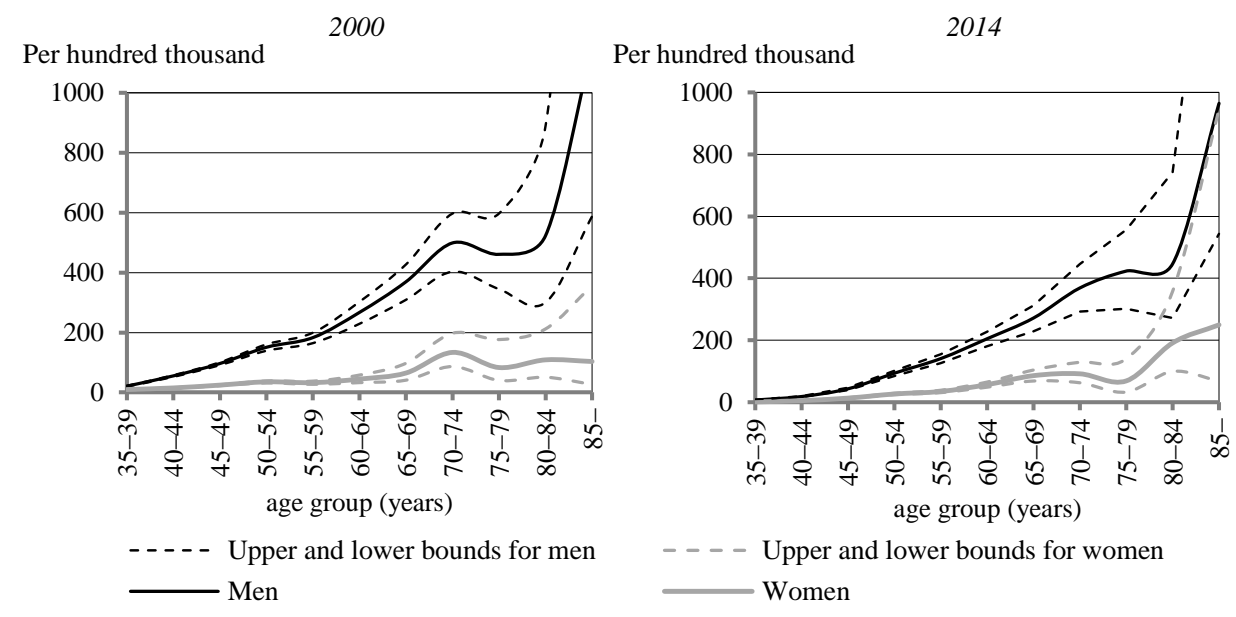

The detailed analysis of smoking-attributable trachea, bronchus and lung cancers as well as ischaemic heart diseases by gender, time series and age group reveals the very different epidemiological nature of these disease groups, too.

1. Naturally, smoking plays a role in a larger part of deaths caused by lung cancer than in deaths due to ischaemic heart diseases. 
2. Nicotine-consumption-related, malignant neoplasms of the lung develop and lead to death at a younger age, therefore, they are faster in progression, spread and more aggressive than ischaemic heart diseases.

3. It is similar in both causes of death that the proportion of tobacco-related mortality within total mortality is generally higher in younger ages than among the elderly. Thus, the role of smoking in early mortality is significant, and - especially through lung cancer - results in a considerable number of years of life lost.

Figure 16. Proportion of smoking-attributable excess mortality in deaths caused by ischaemic heart diseases in the population aged 35 years and over by gender and age group, 2000 and 2014 (with $95 \%$ confidence intervals)

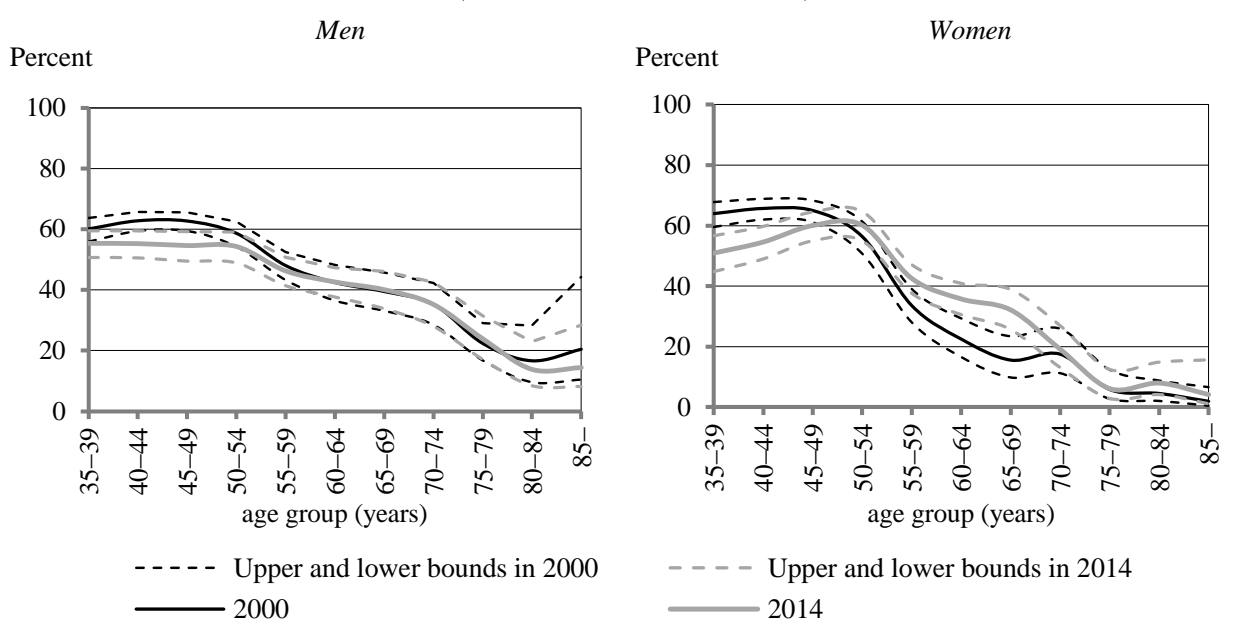

\section{Years of life lost attributable to smoking}

Mortality conditions can be characterised not only by (smoking) specific death rates but also by derived indicators. Besides life expectancies, such an indicator used in statistics is the potential years of life lost, which sums up the (not lived) lifetimes of persons deceased in a certain population group until a fixed age. The selection of age limits is optional, the present study analyses two of them: the 70 years of age used in international practice, and the life expectancy at the age of death. If someone dies, for example, at the age of $x$, then the number of years of life lost is $70-x$ in case $x<70$, while if he/she dies at the age of 70 or over, the indicator is 0 ( $K S H$ [2014] p. 22.). Due to the methodology used in the research, the number of smoking- 
attributable excess deaths is known by age group, which allows the examination of years of life lost.

Table 5

\begin{tabular}{|c|c|c|c|c|}
\hline Year & $\begin{array}{l}\text { Absolute number of those } \\
\text { deceased attributable to } \\
\text { smoking under } 70 \text { years } \\
\text { of age }\end{array}$ & $\begin{array}{c}\text { Smoking attributable } \\
\text { death rate within total } \\
\text { mortality under } 70 \text { years } \\
\text { of age }(\%)\end{array}$ & $\begin{array}{l}\text { Absolute number of years } \\
\text { of life lost attributable to } \\
\text { smoking from the } \\
\text { potential } 70 \text { years }\end{array}$ & $\begin{array}{l}\text { Standardised* years of } \\
\text { life lost attributable to } \\
\text { smoking from the poten- } \\
\text { tial } 70 \text { years per } 100000 \\
\text { persons }\end{array}$ \\
\hline & \multicolumn{4}{|c|}{ Men } \\
\hline \multirow{2}{*}{2000} & 11113 & 29.9 & 129950 & 2824 \\
\hline & 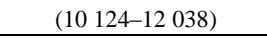 & $(27.3-32.4)$ & (120 321-138 777) & $(2$ 608-3 023) \\
\hline \multirow{2}{*}{2014} & 9398 & 25.3 & 89640 & 1843 \\
\hline & (8 554-10 187) & $(23.0-27.4)$ & $(81872-96864)$ & (1 682-1 992) \\
\hline & \multicolumn{4}{|c|}{ Women } \\
\hline \multirow{2}{*}{2000} & 2904 & 15.6 & 38120 & 725 \\
\hline & (2 444-3 425) & $(13.1-18.4)$ & (34 095-42 263) & $(648-805)$ \\
\hline \multirow[b]{2}{*}{2014} & 3974 & 21.3 & 37267 & 685 \\
\hline & (3 584-4 358) & $(19.2-23.4)$ & (34 023-40 392) & $(626-742)$ \\
\hline
\end{tabular}

* The values were generated for 100000 persons and standardised for the age structure of the European population as recommended by Eurostat.

Note. The brackets contain $95 \%$ confidence intervals.

Since 2000, 1715 fewer men and 1070 more women younger than 70 years of age have died due to smoking, and as a result, the number of the former was 9398 and that of the latter amounted to 3974 in 2014 . While the proportion of smokingattributable deaths within total mortality of men under the age of 70 declined sharply in the reference period, it grew considerably among women. Nevertheless, the absolute number of years of life lost by women decreased between 2000 and 2014, which means that the age at smoking-attributable death shifted more and more to older age groups losing fewer years of life and approached 70 years.

Figure 17 shows the standard values of years of life lost from the potential 70 years per 100000 persons by gender and cause of death for 2000 and 2014. The more than twenty causes of death attributable to smoking are combined in one category. This shares a common set with different groups, e.g. lung cancer with malignant neoplasms and ischaemic heart diseases with diseases of the circulatory system. However, this duplication is not a problem if we want to draw attention to the number of years of life lost due to smoking, since it outlines the magnitude of smokingattributable premature excess mortality compared with other main groups of causes of death (KSH [2014] p. 37.). 


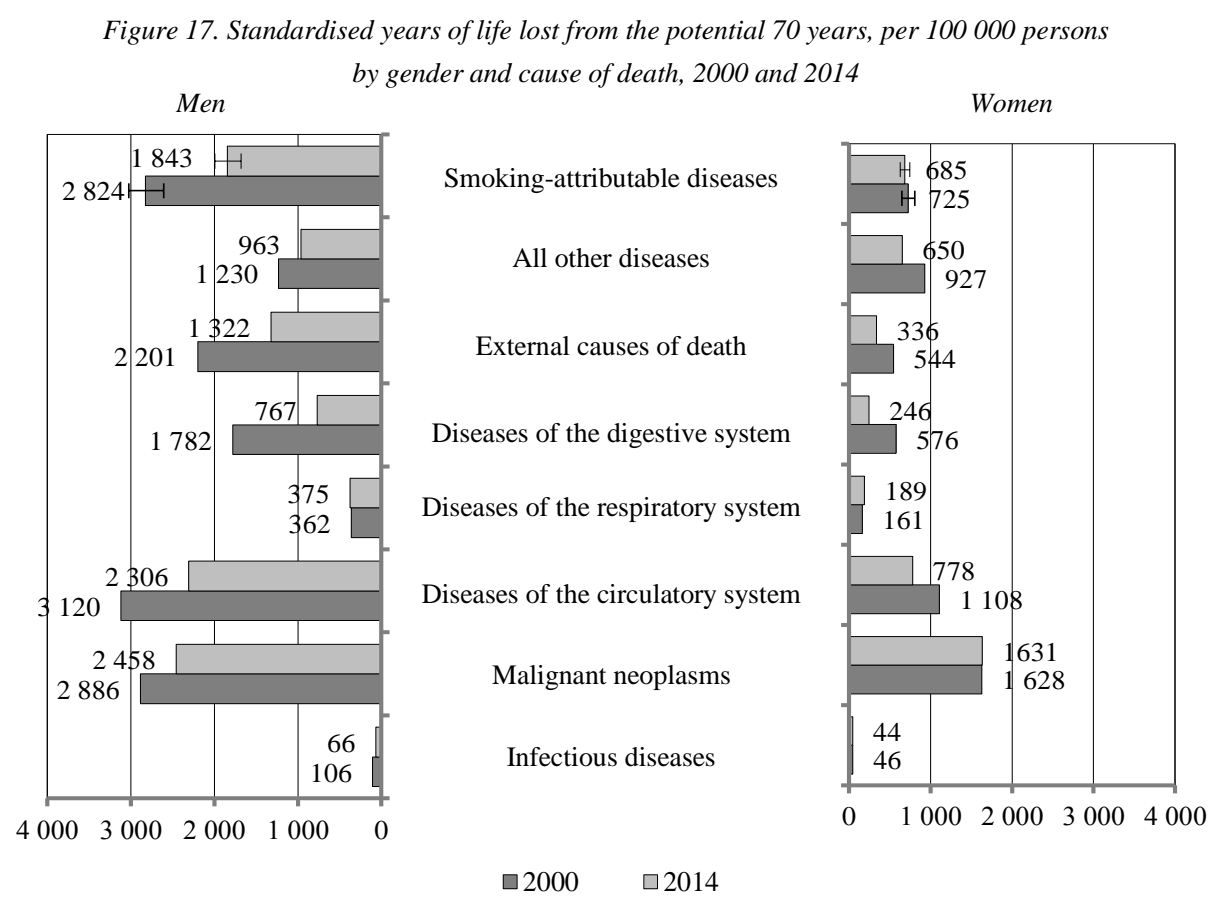

Note. For smoking-attributable diseases, the figure shows the $95 \%$ confidence intervals, too.

As far as years of life lost are concerned, the ranking of the main groups of causes of deaths is similar for both genders. Nowadays, most years of life are lost due to malignant neoplasms. These are followed by the diseases of the circulatory system and not much lagging behind, by the smoking-attributable excess deaths on the third place. It is noteworthy that nicotine dependence alone results in significantly more years of life lost than external causes of death ( $K S H$ [2014] p. 37.). It should be emphasised though that the extent of smoking-attributable premature mortality fell significantly among men in the past one and a half decades. Among women, however, premature mortality due to malignant neoplasms (including deaths caused by lung cancer) has increased notably.

If we compare the years of life lost not to 70 years of age but to life expectancies in different age groups, we can examine older ages as well. In all age groups of men under the age of 55, the number of years of life lost attributable to smoking decreased considerably in the examined period. An important development was in 2014 that the 50-54 age group was a "watershed" among women compared with 2000. The indicator of years of life lost attributable to smoking compared with life expectancy per 100000 persons by age group fell significantly under this age and increased considerably above this until 70 years of age. 
Figure 18. Years of life lost attributable to smoking compared with life expectancy, per 100000 persons by gender and age group, 2000 and 2014 (with $95 \%$ confidence intervals)

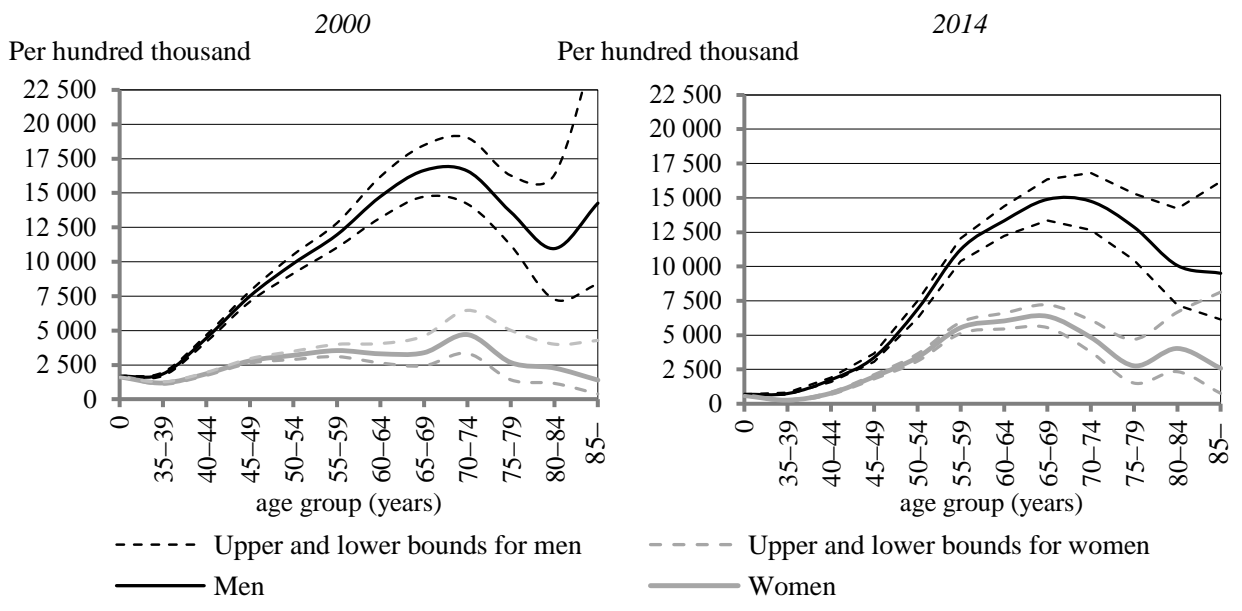

\section{International outlook}

The WHO-HFA database provides an opportunity for the international comparison of smoking-attributable mortality. Contrary to the methodology applied in this study, the indicator in the database significantly overestimates the real values due to its different calculation method. ${ }^{3}$ This chapter provides information on countries with similar culture, historical background and geographic features in the Central European region.

3 "SDR, selected smoking-related causes, per 100 000. Indicator code: E991722.T

SDR is the age-standardised death rate calculated using the direct method, i.e. represents what the crude rate would have been if the population had the same age distribution as the standard European population).

The mortality from combined, selected causes of death which are known from literature to be related to smoking. It has to be pointed out that it is a relatively rough indicator and it is NOT the estimate of tobaccoattributable mortality, which is more complex and difficult to calculate.

This simple pooling of smoking-related deaths (irrespective of what is the actual proportion of deaths due to tobacco in each cause) can help to better rank countries by smoking-related mortality and can be used to better track trends in deaths associated with tobacco than would be possible by using separate causes." (See https://gateway.euro.who.int/en/indicators/hfa_296-1980-sdr-selected-smoking-related-causes-per-100-000/) 
Figure 19. Smoking-attributable standardised death rate per 100000 persons by gender and country, 2013, and its change by gender and country, 2000-2014

Men, 2013

Per hundred thousand

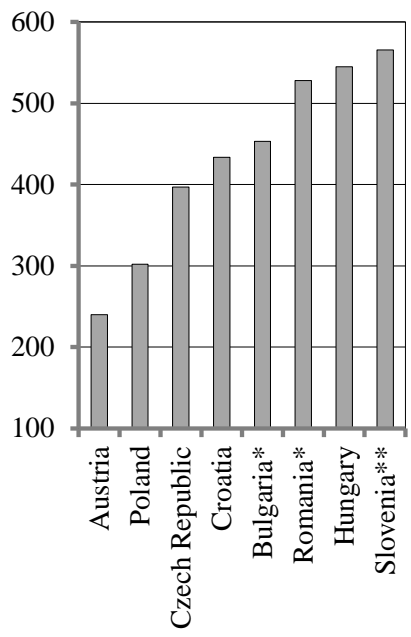

Women, 2013

Per hundred thousand

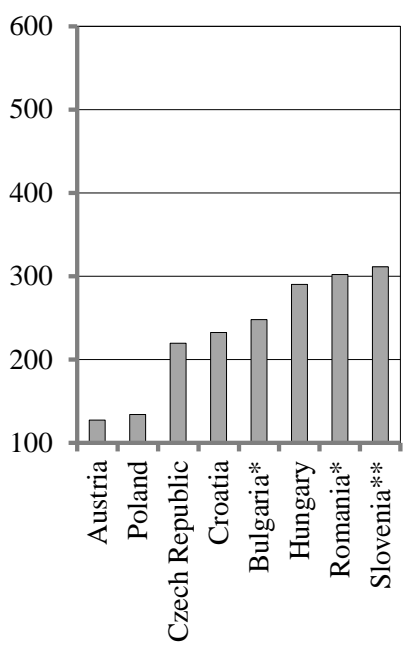

Men $($ change, $2000=100 \%)$

Percent

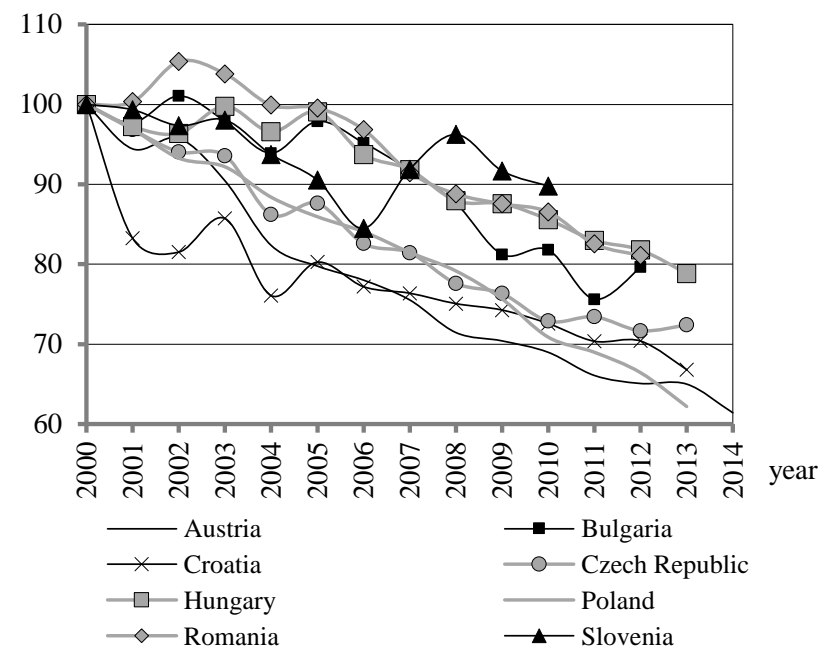

Women $($ change, $2000=100 \%)$

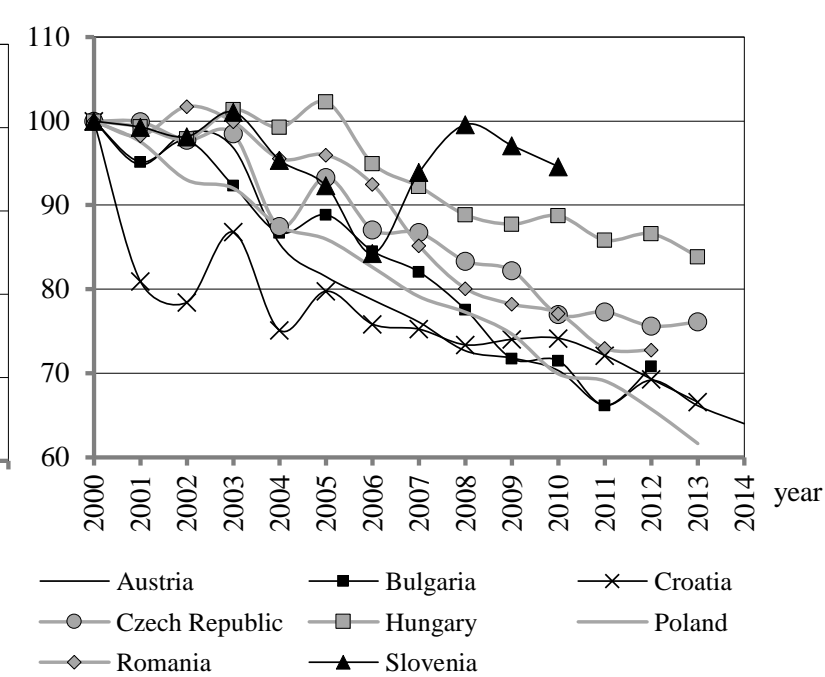

* 2012 data.

** 2010 data.

Source: WHO-HFA database (http://data.euro.who.int/hfadb/). 
By smoking-attributable mortality, these countries can be divided into three groups. Austria and Poland are in the first category where the value of this indicator is the lowest. The Czech Republic, Croatia and Bulgaria are in the second while Romania, Hungary and Slovenia are in the third group with the highest values. In the last one and a half decades, regardless of gender, the value of the smokingattributable standardised death rate decreased significantly in each country, but the rate of decline was different. Among the countries of the region, except for Slovenia, the rate of mortality due to smoking fell to the smallest extent in Hungary. The lagging behind is especially high in the case of women: while the value of the indicator fell by only about $15 \%$ between 2000 and 2013 in Hungary, the decrease was approximately $40 \%$ in Poland. The situation in Austria is considered exemplary because the country has the lowest rate of smoking-attributable mortality in the Central European region and has experienced one of the strongest declines of this indicator since 2000 , regardless of gender.

\section{Summary}

The aim of the research was to quantify the effect of smoking on mortality conditions between 2000 and 2014 in Hungary. One in every two men and one in every three women in Hungary is affected by nicotine addiction. It is good news that over one and a half decades, the number of smokers and ex-smokers (i.e. the base population of smoking-attributable excess mortality) has decreased among both sexes. However, a disadvantageous development is that the proportion of nicotine addicts among older women aged 55-65 has increased significantly since 2000, and no decrease can be observed in the smoking prevalence of the 18-30-year-old population. Approximately one in every five deceased persons dies due to smoking every year in Hungary. Since the turn of the millennium, the smoking-attributable standardised death rate has fallen considerably in the 35-54 age group of both genders, while it has increased significantly in the 55-64 age group of women. The detailed examination of the causes of death structure revealed that chronic diseases, i.e. malignant neoplasms (especially lung cancer) and the diseases of the circulatory system, are the most dangerous for smokers and ex-smokers of both genders. At the same time, the very different epidemiological nature of smoking-attributable trachea, bronchus and lung cancers and ischaemic heart diseases is revealed, too: malignant neoplasms develop and lead to death at a younger age, therefore, they are faster in progression and are more aggressive than ischaemic heart diseases. In this respect, the situation of smoking women is especially alarming: the smoking-attributable standardised death rate due to trachea, bronchus and lung cancers per 100000 women grew drastically, by $60 \%$ (!) 
between 2000 and 2014. It is explained by the worsening mortality rate of 50-70year-old women that is caused by their increasing nicotine dependence, which has had an adverse effect on their premature mortality as well. "The accelerating emancipation, the blurring difference between gender roles, and thus, the increasing level of stress, in other words, the »masculinising « lifestyle of women may be the background to this. At the same time, the higher extent of premature mortality of men and the phenomenon of divorces can fundamentally change the family bonds of middle-aged women." (KSH [2014] p. 40.) There is a pressure to cope with these changes, which may cause that the affected persons increase the consumption of tobacco and alcohol, even if it is self-destructive. In addition, the examination of years of life lost revealed that the relevance of smoking-related diseases has overtaken that of external causes of death for both genders. Due to the magnitude of excess mortality caused by this addiction, smoking has had a significant impact on Hungary's mortality from the turn of the millennium until now. Nicotine dependence has considerably slowed down the downward trend in mortality between 2000 and 2014; its contribution to the natural decrease was determinant ( $K S H$ [2014] p. 38.). In the past one and a half decades, this addiction claimed more than 370 thousand lives in Hungary. It should be stressed that there is still a lot to be done in the field of improving smoking-attributable mortality conditions in Hungary, which is also proven by the fact that, according to the international outlook, the lagging behind of Hungary is significant compared with the other countries of the region.

\section{References}

BöTI, E. - KonCZ, B. - VITRAI, J. [2011]: A felnőttek dohányzására vonatkozó magyarországi felmérések adatai, 2000-2009. Országos Egészségfejlesztési Intézet, Dohányzás Fókuszpont. Budapest. http://www.fokuszpont.dohanyzasvisszaszoritasa.hu/sites/default/files/dohanyzasra_vonatkozo _felmeresek_adatai_2000_2009.pdf

Doll, R. - Hill, A. B. [1950]: Smoking and carcinoma of the lung. British Medical Journal. Vol. 2. Issue 4682. pp. 739-748. http://dx.doi.org/10.1136/bmj.2.4682.739

KSH [2002]: A dohányzás hatása a halandóságra Magyarországon 1970-1990. Budapest.

KSH [2014]: A haláloki struktúra változása Magyarországon, 2000-2012. Budapest. https://www.ksh.hu/docs/hun/xftp/idoszaki/pdf/halalokistruk.pdf

LEvin, M. L. [1953]: The occurrence of lung cancer in man. Acta - Unio Internationalis Contra Cancrum. Vol. 9. No. 3. pp. 531-541.

Shultz, J. M. - Novotny, T. E. - Rice, D. P. [1991]: Quantifying the disease impact of cigarette smoking with SAMMEC II software. Public Health Reports. Vol. 106. No. 3. pp. 326-333.

Thun, M. J. - Carter, B. D. - Feskanich, D. - Freedman, N. D. - Prentice, R. - Lopez, A. D. HARTGE, P. - GAPSTUR, S. M. [2013]: 50-year trends in smoking-related mortality in the United States. The New England Journal of Medicine. Vol. 368. No. 4. pp. 351-364. http://dx.doi.org/ 10.1056/NEJMsa1211127 
U.S. HHS CDC NCCDPHP (Department of Health and Human SeRvices, Centers for Disease Control and Prevention, National Center for Chronic Disease Prevention and Health Promotion) Office on Smoking AND Health [2014]: Smoking-attributable morbidity, mortality, and economic costs - Chapter 12. In: The Health Consequences of Smoking - 50 Years of Progress: A Report of the Surgeon General. Atlanta. pp. 647-680. http://www.cdc.gov/tobacco/data_statistics/sgr/

Vitrai, J. - BAKACS, M. - BALKU, E. - Bodrogi, J. - DemjÉn, T. - Joó, T. - VÁmos, M. - Vokó, Z. [2012]: A dohányzás társadalmi terhei Magyarországon. Kiemelt megállapitások. Országos Egészségfejlesztési Intézet. Budapest. http://docplayer.hu/3331194-A-dohanyzas-tarsadalmiterhei-magyarorszagon.html

VoKó, Z. [2009]: A dohányzás visszaszorítása, mint kiemelt népegészségügyi prioritás. IME Interdiszciplináris Magyar Egészségügy. Vol. VIII. No. 3. pp. 35-39. 